\title{
Applying machine learning algorithms in spatial piping erosion susceptibility in Zarandeieh watershed, Central Iran
}

\author{
Saeid Janizadeh ${ }^{1}$, Kourosh Ahmadi ${ }^{1}$, Sunil Saha ${ }^{2}$, Kaustuv Mukherjee ${ }^{3}$, Saeid Khosrobeigi \\ Bozchaloei $^{4}$, and Artemi Cerdà ${ }^{5}$ \\ ${ }^{1}$ Tarbiat Modares University \\ ${ }^{2}$ University of Gour Banga \\ ${ }^{3}$ Chandidas Mahavidyalaya \\ ${ }^{4}$ Tehran University \\ ${ }^{5}$ University of Valencia
}

May 7, 2020

\begin{abstract}
Soil erosion is threatening land sustainability. Piping erosion is one of the land degradation processes that lead to significant landscape and environmental changes, and request a proper mapping survey. The purpose of this study is to survey piping erosion susceptibility maps in Zarandeieh watershed of Markazi province using Random Forest (RF), Support Vector Machine (SVM), and Bayesian Generalized Linear Models (Bayesian GLM) machine learning methods. For this purpose, due to the influence of different physiographic, environmental and soil conditions on the development and formation of piping, 18 variables were considered for modeling the piping erosion sensitivity in Zarandieh watershed. Based on field surveys and aerial photographs, 152 points of piping erosion were identified in the studied area, $70 \%$ of which was used for modeling, and $30 \%$ for model validation. The area under curve (AUC) was used to evaluate the performance of the models used. The results of the pipping erosion susceptibility showed that all three RF, SVM and Bayesian GLM models, have a good performance in the validation stage such as the AUC shown with values of 0.9 for RF, 0.88 for SVM, and 0.87 for Bayesian GLM. Altitude, PH and Bulk density are the variables that had the most impact on the pipping erosion sensitivity in the study area. This result shows that topographical and soil chemical factors are responsible for the piping distribution in the Zarandieh watershed.
\end{abstract}

\section{Hosted file}

Pipping manuscriptLDD.docx available at https://authorea.com/users/319335/articles/449189applying-machine-learning-algorithms-in-spatial-piping-erosion-susceptibility-inzarandeieh-watershed-central-iran

\section{Hosted file}

Figures.docx available at https: //authorea.com/users/319335/articles/449189-applying-machinelearning-algorithms-in-spatial-piping-erosion-susceptibility-in-zarandeieh-watershedcentral-iran 